\title{
PRICE LEVEL AND BRAND KNOWLEDGE AND ITS EFFECTS ON PURCHASE BEHAVIOR
}

\author{
NÍVEL DE PREÇO E CONHECIMENTO DE MARCA E SEUS \\ EFEITOS NO COMPORTAMENTO DE COMPRA
}

\author{
Deonir De Toni ${ }^{1}$ \\ Andressa Tormen ${ }^{1}$ \\ Gabriel Sperandio Milan² \\ Luciene Eberle ${ }^{2}$ \\ Fernanda Lazzari ${ }^{1}$ \\ Ana Paula Graciola² \\ 1 Universidade de Caxias do Sul (UCS), Caxias do Sul/RS - Brazil. \\ 2 Universidade do Vale do Rio dos Sinos (Unisinos), São Leopoldo, Rio Grande do Sul, Brazil.
}

Submission: $10 / 05 / 20$

Accept: 09/04/21

\begin{abstract}
Purpose: this study aims to examine the impacts of price levels, high level vs. low level, associated to a known brand vs. an unknown brand over fairness perception, symbolism quality and purchase intention.

Design/methodology/approach: one pre-experiment is conducted with a 2 (high price level vs. low price level) x 2 (known brand vs. unknown brand) between-subjects design and a sample of 152 jeans customers.

Finding: the results indicate that different price levels with brand knowledge or without brand knowledge impact differently over customer behavior, mainly when it comes to quality, fairness, perceived value, symbolic value and purchase intention of the investigated product and that that the relation between symbolic value and purchase intention is totally mediated by the perceived fairness.

Practical Implication: by understanding how customers integrate, relate and infer quality, fairness and symbolic aspects to products through their perceptions concerning price levels and brand knowledge levels, it is possible to supply marketing professionals with information that lead to better-informed choices about pricing policy and branding in their companies.

Originality/value: among these research contributions, we emphasize the proposition of eleven research hypotheses that aim to better understand customer behavior from the manipulation of two variables: product price level and brand knowledge level and its impact on perceived quality, fairness, symbolism and purchase intention.
\end{abstract}

Keywords: price level, brand knowledge, symbolic value, purchase intention. 


\section{RESUMO}

Objetivo: este estudo tem como objetivo examinar os impactos dos níveis de preços, alto e baixo nível, associados a uma marca conhecida vs. uma marca desconhecida, sobre percepção de justiça, qualidade do simbolismo e intenção de compra.

Design/metodologia/abordagem: um pré-experimento é conduzido com um design entre sujeitos de 2 (alto nível de preço vs. baixo nível de preço) x 2 (marca conhecida vs. marca desconhecida) e uma amostra de 152 clientes de jeans.

Resultados: os resultados indicam que diferentes níveis de preços com conhecimento de marca ou sem conhecimento de marca impactam de forma diferenciada no comportamento do cliente, principalmente no que diz respeito à qualidade, justiça, valor percebido, valor simbólico e intenção de compra do produto investigado e que a relação entre valor simbólico e a intenção de compra é totalmente mediada pela justiça percebida.

Implicações gerenciais: ao compreender como os clientes integram, relacionam e inferem qualidade, justiça e aspectos simbólicos dos produtos por meio de suas percepções sobre os níveis de preços e níveis de conhecimento da marca, é possível fornecer aos profissionais de marketing informações que levam a escolhas mais bem informadas sobre política de preços e marcas em suas empresas.

Originalidade/valor: dentre essas contribuições, destacamos a proposição de onze hipóteses de pesquisa, que visam entender melhor o comportamento do cliente a partir da manipulação de duas variáveis: nível de preço do produto e nível de conhecimento da marca e seu impacto na qualidade, justiça, simbolismo e intenção de compra.

Palavras-chave: nível de preço, conhecimento da marca, valor simbólico, intenção de compra.

\section{INTRODUCTION}

Both different price levels and brand knowledge level, as well as brand image, can significantly interfere or influence customer behavior. Price and brand are the main factors that can impact the customer purchase journey (Zielke, 2010). For so, price decisions and brand investment are important elements, which managers must consider when shaping marketing strategies (De Toni \& Mazzon, 2014). Koschate-Fischer and Wüllner (2017) in a meta-analysis between 2005 and 2015 identify there is little research in price image. There is little research that tries to understand the price image nature, background, and consequences (Lombardt et al., 2017). Therefore, this theme is emerging as a gap that should be investigated.

For brands, it is particularly relevant to understand how the interplay between the brand and the price level influence the price image. There are different attributes that can influence the purchase intention of a product or organization, but the price and the brand image are one of the most important (Pizzinato et al., 2020). When the customers have incomplete information about the objects than they are considering buying, the price and brand have one important influence on the consumer decision. Well-known brands associated with a superior price and superior quality induce the customer to fairness perception and superior value (cognitive factors) and, in some cases, to a higher status (affective factors). Brands with high prices and high quality are associated to high reputation that reinforces their self-concept (Lichtenstein, Ridgway, \& Netemeyer, 1993; Vigneron, \& Johnson, 1999). Consequently, different price levels associated with brand knowledge indicate a different way of understanding the diverse dimensions that build price image.

For this reason, the investigation of different price levels and brand knowledge level influence over customer perception and purchase behavior is relevant. In this direction, the present research search to identify how different price level and known vs unknown brands interfere in the quality perception, fairness, symbolism and purchase intention. This finding help to understand better the direct, mediate and moderate relation between the price level and brand knows vs unknown 
brand in the consumer behavior. Therefore, this research shows how consumers react to price and how this reaction depends on brand knowledge.

For so, 152 respondents participated in a pre-experiment with a 2 (price high level vs. low level) $\times 2$ (known brand vs. unknown brand) between-subjects design and evaluated four different purchase situations scenarios. The results indicate that from the eleven proposed hypotheses, just three were not confirmed, evidencing that the theoretical approach proposed is consistent with the empirical results. Therefore, the results indicate that different price levels with brand knowledge or without brand knowledge impact differently over customer behavior, mainly when it comes to quality, fairness, perceived value, symbolic value and purchase intention of the investigated product.

Existing research has mostly addressed inference drawn from price positioning (Anselmsson and Johansson, 2014; Zielke, 2014) and brands (Aaker, 1991) separately. Research analyzing effect of their interaction on price image dimensions is scarce. In this way, among the contributions of this study, four can be highlighted. The first is the integration and relation between perceived quality, perceived fairness, and symbolic value and the identification of the effects that different price levels and brand knowledge or not may cause over purchase intention.. The second is the identification of the perceived quality and fairness as a mediating variable that impacts purchase intention. The third is the use of price level and brand knowledge level as moderating variables that influence purchase intention. The fourth contribution is the integration of price and brand in one pre-experiment that presented their effects conjointly over purchase behavior. In this way, different price levels associated with brand knowledge or not interact differently over purchase intention and knowing these effects is very relevant for the marketing management to improve their investment in the brand and in pricing strategy.

\section{THEORETICAL BACKGROUND}

\subsection{Price levels and brand knowledge}

The price level perception refers to how cheap or expensive the customer perceives an organization, product, service or brand (Zielke, 2010). Price level perception not only influences value and purchase intention, but also a low price indicates to inferior quality and little symbolic value. So, for example, when the customer is not able to judge a product or brand quality, the price level can be an information cue. By the way, Inference Theory assumes that the individuals use information cues to infer about certain objects. In the purchase behavior, such inferences become relevant when the customers have incomplete information about the objects they are considering buying (Nisbett \& Ross, 1980). It is worth noting that Inference Theory anchors the idea that price level is not just an antecedent of value for money, but can also infer quality, fairness, perceived value and brand symbolism (Peter \& Olson, 2010).The price perception has rational elements (Hamilton and Chernev, 2010) and affective elements (Lombart et al., 2016, Koschate-Fischer and Wüllner, 2017, Zielke, 2011). The strength of the brand can evoke both emotional and rational factors, making it less sensitive to the action of competitors on price, because it is more present in the consumer's mind and generates the possibility of charging a premium price (Anselmsson et al., 2014).

Gouvêa et al. (2018) show that the brands have played a prominent role in purchase and sale relationships and the people attribute higher price for manufacturer brand than the generic brand. In an experiment of De Toni et al. (2014) with known brand vs. unknown brand and high price vs. low price, it was found that purchase intention both in situations of low prices as well as high prices is significantly higher for luxury perfume known brands; the perception of quality for perfume known brands is significantly greater than that for unknown brands, regardless of the price level. Consequently, different price levels associated with brand knowledge indicate a different way of 
understanding the diverse dimensions that build price image. Well-known brands associated with a superior price and superior quality induce the customer to fairness perception and superior value (cognitive factors) and, in some cases, to a higher status (affective factors). Brands with high prices and high quality are associated to high reputation that reinforces their self-concept (Lichtenstein, Ridgway, \& Netemeyer, 1993; Vigneron, \& Johnson, 1999; De Toni \& Mazzon, 2014).

\subsection{Perceived quality}

The price level is important to evaluate quality because it offers heuristic cues about the product. The heuristic cues or hints are generally used as a type of mental shortcut to simplify an object or an event evaluation, mainly when the individuals are not motivated to process the information or when the decisions are less important (Yeung \& Soman, 2007). In this sense, Zeithaml (1988) affirms that, when there are no other inferences about a product's quality, the customer uses price and brand to indicate if a product has or does not have quality.

The role of quality perception is to influence customers in their choices and purchase and consumption behaviors (Sheau-Fen, Sun-Way, \& Yu-Ghee, 2012). According to Keller (1993), brand knowledge can be understood through the customer brand past experience and memory. Therefore, if customers are satisfied with the product overall satisfaction, they will be committed and motivated to buy other products from the same brand (Chung \& Lee, 2017). The quality of a brand is enhanced by tangible items (such as product performance, durability...), and by emotional or intangible aspects that increase the perceived quality (Gouvêa et al., 2018; Kapferer, 2004). In this context, quality perception involves a variety of relevant variables when explained and compared among brands, emphasizing quality as the highest impact factor in the brand role and preference, more important than the price itself (Sheau-Fen, Sun-Way, \& Yu-Ghee, 2012).

Há-Brookshire (2012) emphasizes there is a strong correlation between price and perceived quality, mainly when the price is high because this element presents a compensatory strategy in relation to information processing before the customer decides on the product or not. This evidences that customers relate the product's quality level to its price level, reducing perceived risk and affecting their intention or purchase decision (Newman et al., 2014).

Himbert (2016) identified in previous studies, such as Shapiro (1973) and Scitoyszky (1945), which had already found that price is used as an external cue to assess the quality of the product, and higher prices lead the customer to suppose that the product has higher quality. Dodds, Monroe, and Grewal (1991) identified that price has a positive effect on the product quality perception, and the more price is perceived as high, the greater the perceived quality of the product (Lichtenstein, Ridgway, \& Netemeyer, 1993; Sweeney, Soutar, \& Johnson, 1999; Himbert, 2016).

The same happens in relation to brands. Researches have demonstrated that price is mostly used to suggest quality when the brands are not familiar (O'Neill \& Lambert, 2001). There are a variety of factors that can moderate price and quality relation. For Himbert (2016), besides brand, there are moderators related to the customer, the organization, the product characteristics, time pressure, etc.

Price as the product or service extrinsic attribute is frequently used by customers as a cue to judge quality (Hansen, 2005). Perceived risk in a purchase situation is one of the main reasons why price guides and influences quality evaluation (Diller, 2008). This way, the first potential product moderator that may impact this relation is the brand. Brands with high reputation have a positive influence in the perceived price-quality relation, and these brands lead to a higher quality perception, higher perceived value and an increase in purchase intention (Dodds \& Monroe, 1985; Monroe \& Krishnan, 1985; Zielke, 2010, 2011). Therefore, there is a lot of evidence that people use the price 
and brand as heuristic hints to evaluate the perceived quality and value of a product or service. From this reflection, the following research hypotheses were established:

H1a: Products with high price levels and known brands are perceived as of higher quality than products with low price levels and known brands.

H1b: Products with high price levels and unknown brands are perceived as of higher quality than products with low price levels and unknown brands.

H1c: Quality perception of known brand products is significantly higher than the quality perception of unknown brand products, both for high price levels and low price levels.

\subsection{Perceived fairness}

Bolton, Warlop and Alba (2003) affirm that price fairness is an evaluation of an equation result, where the customer evaluates a reasonable, acceptable and fair pattern. In this sense, the customers use past prices from different periods of time to build their expectations and make their consumption or purchase choices (Yuan \& Han, 2011). In addition, it is worth mentioning the expression "it is expensive, but it is good", which denotes that, even paying more for the product, customers identify that such price can be fair because they find meaning in the product and for the benefits they get (De Toni \& Mazzon, 2014).

For Kukar-Kinney, Xia and Monroe (2007), the fairer the judgment of monetary value, the greater the purchase and repurchase intentions. Such factor reinforces the supposition that greater levels of unfairness connected to price may make the customer choose to look for other purchase options, changing brands, products or even the supplier (De Toni, Mazzon, \& Milan, 2015).

Price (un)fairness perception is related to a subjective sense of a right, fair or genuine price vs. a wrong, unfair or irregular price. Such price (un)fairness perception is a fundamental key in marketing, such as the intention to pay and the product or brand perceived value (Campbell, 2007).

With regard to price comparison and perception of fairness, Hamilton and Chernev (2013) indicate that consumers are more likely to judge a price difference as unfair if these differences occur between two low-priced establishments. In this sense, among the factors that impact the perception of price justice, Xia, Monroe and Cox (2004) indicate that when consumers pervvceive two business transactions as similar, but in one the price is higher than in another, in this case, there will be a perception that the price is unfair. This can be observed in situations of perceived similar brands, both known and unknown, and those with lower prices will be perceived as fairer. From this assumption, it can be inferred that in situations of perceived similarity between brands, the perception of fairness may be higher in low price brands.

In one another observation, Xia et al. (2004) identity than one consumer perceived more fairness in situation that have more trust. In this case, known brand can be perceived how more trust that unknown brand and in this case to be perceived how more fairness. For this reason, the following research hypotheses are presented:

H2a: In the similarity perception between brands, as known brand as unknown brand, the fairness perception is significantly higher for low price levels than high price levels.

H2b: The fairness perception is significantly higher for known brand products than for unknown brand products, both for high and low price levels. 


\subsection{Symbolic value}

When buying a product, an individual considers its symbolic attributes, that is, what represents him and is significant for him and for others (Levy, 1981; Dichter, 1985). People do not buy objects only due to what they can perform, that is, their utilitarian value, but mainly, due what they mean (Dobni \& Zinkhan, 1990; Stern, Zinkhan, \& Jaju, 2001, De Toni \& Mazzon, 2014).

A product or brand symbolism is related to the ability of signal status and reinforce the user (customer) self-concept (Park, Jaworski, \& Macinnis, 1986; O'Cass \& Frost, 2002). In the last years brands no longer have only a bureaucratic or utilitarian purpose and take on the responsibility of reducing the importance of price in buying decision, by influencing the perception of the products value (Gouvêa et al., 2018). Therefore, high-priced brands are associated with high prestige and status for their users or buyers, thus enhancing their self-concept (Lichtenstein, Ridgway, \& Netemeyer, 1993). In this way, the brand adds value (in intangible as well as in tangible benefits) that the buyer is willing to pay (Gouvêa et al., 2018; Kapferer, 2004)

High-status brands serve to justify high prices, where consumption status is a motivational process in which the individual aims to improve the social status through the consumption of noticeable products that confer or symbolize status for themselves or their environment (Goldsmith, Flynn, \& Kim, 2010).

Thus, it appears that increments in the symbolic dimension would be associated with the customer view of improvements in the product, brand or organization price image and, consequently, in perceived value and purchase intention (De Toni \& Mazzon, 2014). Facing the exposed, the following research hypotheses emerge:

H3a: High price level products and known brands are perceived as having greater symbolic value than low price level products and known brands.

H3b: High price level products and unknown brands are perceived as having greater symbolic value than low price level products and unknown brands.

H3c: Known brands symbolic value is significantly higher than unknown brands, both for high and low price levels products.

\subsection{Purchase intention}

The intention is understood as the decision of acting in a certain way in the future (Ramayah, Lee \& Mohamad, 2010). Intentions reflect motivational factors that influence the person' behavior and, the higher the intention in engaging in certain behavior, the higher the probability it happens (Ajzen, 1991). For so, in general, purchase intention may predict or determine a real future behavior, that is, predict the conclusion of a purchase act (Ramayah, Lee \& Mohamad, 2010).

Gouvêa et al (2018) in a study with 248 consumers of T-shirt identified that the most important attributes that influence purchase preference of this product are first the quality, second the brand type, and third the price. Therefore, different price levels associated with brand knowledge indicate a distinctive form of perceiving the different dimensions that build price image and purchase intention. Well-known brands associated with a superior price and superior quality induce the customer to fairness perception and superior value and, in some cases, to a higher status. High price and high-quality brands are associated with high prestige that reinforces their self-concept (Lichtenstein, Ridgway, \& Netemeyer, 1993; Vigneron \& Johnson, 1999; De Toni et al., 2015).

However, a low price can be one of the main purchase or consumption drivers for both known and unknown brands. In this sense, the better customers' perceptions of prices (levels), the greater their willingness to pay higher prices and the better their purchase or repurchase intentions 
(Olaru, Purchase, \& Peterson, 2008). Therefore, the following research hypothesis was formulated:

H4: Low price levels products have a higher purchase intention than high price levels products, both for known and unknown brands.

\subsection{The mediation-moderation of price level and brand knowledge}

Some constructs indicate to have a direct effect over a dependent variable, but they can also have an indirect effect through other variables (Preacher \& Hayes, 2008). In this case, the symbolic value of a product or brand may not directly impact purchase intention but may be strongly related to perceived value, quality, and fairness, that, in turn, impact over customers purchase intention (Graciola et al., 2018).

According to Hair Jr. et al. (2010), the moderating effect occurs when a third variable or construct changes the relationship between two variables or related constructs. Therefore, the moderating variables are introduced to verify the effect of external variables over the relations in a model. Thus, this study intends to verify the moderating effects of price level and brand knowledge over purchase intention through the mediation of quality, fairness and value perception. In this sense, Zielke $(2010$; 2011) points two main types of moderation related to purchase behavior and their consequences: (i) moderators related to the customer; and (ii) moderators related to the object characteristics (i.e, product, service or brand). As for this study, price levels are a characteristic of the evaluated object (product) and that brand knowledge levels are moderators related to the customer.

In particular, it is possible to assume that perceived quality can be lower in situations in which the price offered is low, resulting in negative quality perception. On the other hand, high prices were associated with a higher reputation and quality brands (Völckner \& Hofmann, 2007). Once price level perception (low price) must have a negative impact over a brand symbolic value, a brand quality perception has a positive effect over symbolic value. Therefore, different price levels and knowledge brand levels impact differently and indirectly over purchase behavior and also have the mediation of quality, fairness and value perception (De Toni \& Mazzon, 2014).

A survey conducted with 450 consumers with two large retail chains of construction material in three cities of São Paulo state for Pizzinato et al. (2020) identifies that the symbolic aspects as relationship, service, convenience, and brand with the cognitive or utilitarian aspect as price, point of sale, product and promotion can be considered the most valued attributes by consumers when choosing a store to purchase. Therefore, researches concerning product value perception have shown that price level and brand quality perception are important antecedents of perceived value and fairness (Zeithaml, 1988; Teas \& Agarwal, 2000; Zielke 2010; De Toni \& Mazzon, 2014) and, such value perception partially mediates the impact of price levels perception over behavioral intentions (Chang \& Wildt, 1994), as for this study, considering purchase intention. In this direction, it is possible to present the following research hypotheses:

H5a: The symbolic value of the product evaluated in this study (jeans), with high price levels and unknown brand demonstrates a greater indirect effect over purchase intention; while for low price levels no significant difference for both known and unknown brands, considering the product perceived quality as mediating variable;

H5b: The symbolic value of the product evaluated in this study (jeans), with high price levels and unknown brand demonstrates a greater indirect effect over purchase intention; while for low price levels no significant difference for both known and unknown brands, considering the product perceived fairness as mediating variable; 


\section{RESEARCH METHOD}

In order to test the research hypotheses, this research was developed through the experimental technique. The method was operationalized by means of the between-subjects design, in which each sample group is exposed to a single experiment scenario (Lehmann, Gupta, \& Steckel, 1998). The product used for the research development, among clothing products, the jeans, was chosen because it is a widely known product and frequently worn by the experiment participants, besides presenting several brands and diversified price levels.

\subsection{Scenarios design and experiment procedures}

Facing the exposed, the experiment was delineated with a 2 (price: high; low) $\times 2$ (brand: known; unknown) between-subjects design. The experiment design can be clearly observed in Table 1 .

Table 1: Pre-Experiment Scenarios

\begin{tabular}{c|c|c}
\hline Brand Levels and Price Levels & High Price & Low Price \\
\hline Known Brand & $\begin{array}{c}\text { Scenario 1 } \\
\text { HP_KB }\end{array}$ & $\begin{array}{c}\text { Scenario 2 } \\
\text { LP_KB }\end{array}$ \\
\hline Unknown Brand & $\begin{array}{c}\text { Scenario 3 } \\
\text { HP_UB }\end{array}$ & $\begin{array}{c}\text { Scenario 4 } \\
\text { LP_UB }\end{array}$ \\
\hline
\end{tabular}

Source: Elaborated by the authors.

Note: HP = High Price; LP = Low Price; KB= Known Brand; UB= Unknown Brand.

In order to avoid possible biases, the questionnaires were handed out following the procedure suggested by Kardes (2002), with complete randomization among the participating subjects. Therefore, the questionnaires were randomly handed out, enabling that any of the four scenarios could be answered by any research participant. Although this care was taken, this kind of sample must be classified as non-probabilistic, by convenience, in which the respondents are chosen by the researchers' own criteria, without any statistical inference (Malhotra, Birks, \&Wills, 2012).

It is worth noting that price levels, high and low, were defined according to previous exploratory study results, with the same kind of participants. Also, in order to avoid research biases, brands were not indicated, neither in the known brand scenarios (KB) nor created a brand to configure as an unknown brand (UB). Thus, it was pointed out in the known brand (KB) scenarios that the product was about a reputed jeans brand, known in Brazil and abroad. And, for the unknown brand (UB) scenarios, it was indicated that the product was one that the buyer did not know the brand. This exploratory study results identified that, on average, $\mathrm{R} \$ 89,00$ (Brazilian currency) is considered a low price for jeans, and $\mathrm{R} \$ 298,90$ (Brazilian currency) could be considered a high price for this product.

\subsection{Data collection instrument and data analyses}

Data collection instrument applied was elaborated from previous studies validated scales, as shown in Table 2, being its content validity performed through the evaluation by three marketing and consumer behavior experts (Malhotra, Birks, \&Wills, 2012). For the questionnaire operationalization, we used a seven-point Likert scale with the extremes " 1 . Totally Disagree" to "7. Totally Agree". 
Table 2: Structuring Data Collection Instrument

\begin{tabular}{|c|c|c|}
\hline Constructs & Scale Items & Authors \\
\hline Perceived Quality & $\begin{array}{l}\text { 1. This product is of good quality. } \\
\text { 2. This product's quality is perfectly acceptable. } \\
\text { 3. This product's quality is better compared to other brands. } \\
\text { 4. This is a high-quality product. }\end{array}$ & $\begin{array}{l}\text { Sweeney, Soutar } \\
\text { Johnson (1999) }\end{array}$ \& \\
\hline Perceived Fairness & $\begin{array}{l}\text { 1. This product is sold at a fair price. } \\
\text { 2. This product is sold at an acceptable price. } \\
\text { 3. This product's price is justified. } \\
\text { 4. This product is sold at a reasonable price. }\end{array}$ & Zielke (2006) \\
\hline Symbolic Value & $\begin{array}{l}\text { 1. This product will make me feel more powerful. } \\
\text { 2. This product will give me a prominent position in society. } \\
\text { 3. This product will contribute to increasing my status. } \\
\text { 4. This product will favorably improve other people's per- } \\
\text { ception of myself. }\end{array}$ & $\begin{array}{l}\text { De Toni \& Mazzon } \\
\text { (2014) }\end{array}$ \\
\hline Purchase Intention & $\begin{array}{l}\text { 1. This product would be a good purchase. } \\
\text { 2. I would recommend this product to a friend. } \\
\text { 3. It is likely that I make positive comments about this prod- } \\
\text { uct to other people. } \\
\text { 4. I would consider this product to buy. } \\
\text { 5. I will probably purchase this product in the future. } \\
\text { 6. I will acquire this product on my next purchase. }\end{array}$ & Barber et. al. (2012) \\
\hline
\end{tabular}

Source: Elaborated by the authors.

The researchers performed the questionnaire content validity and face or nominal validity (Kinnear \& Taylor, 1996). Such evaluation concerns a subjective and systematic evaluation of the scales used and the structure of the data collection instrument as a whole (Malhotra, Birks, \& Wills, 2012), aiming to verify how much each variable comprehends the construct under analyses and whether its language and structure is appropriate (Hair Jr. et. al., 2010).

After data collection, aiming to validate the constructs, we performed the unidimensionality, reliability, convergent validity, and discriminant validity analyses. The results evidenced that all constructs and their corresponding indicators present adequate results, as recommended by the literature (Hair Jr. et. al., 2010; Malhotra, Birks, \& Wills, 2012).

\subsection{Pre-Experiment participants}

The pre-experiment was applied to a Bachelor's Degree in Business Administration students, in a University in southern Brazil. This audience used in experimental approaches is defended in the literature because it allows homogeneity among participants (Peterson, 2001), what tends to increase the study internal validity (Peterson, 2001), as well as the reliability of the conclusions derived from the variables and manipulated scenarios (Wilson, Aronson, \& Carlsmith, 2010).

Data were collected between June $4^{\text {th }}$ and June $8^{\text {th }}, 2018$, and resulted in a sample of 159 students. The collection of the data was in the laboratory of the University, where the respondents were conducted to an individual computer to answer the questions of each scenery. Each pre-experimntal group presented at least 35 valid cases, as follows: (i) 43 valid cases in Scenario 1 (High Price and Known Brand; HP_KB); (ii) 37 valid cases in Scenario 2 (Low Price and Known Brand; LP_KB); (iii) 38 valid cases in Scenario 3 (High Price and Unknown Brand; HP_UB); and, finally, and (iv) 41 valid cases in Scenario 4 (Low Price and Unknown Brand; LP_UB). 


\subsection{Manipulation check and control variables}

In order to establish the manipulation check, the respondents' perceptions in relation to the presented scenarios were verified. For this reason, the first questionnaire question refers to the Scenario Realism, where the participants needed to answer about "how realistic is the presented scenario". In a seven-point Likert scale, the mean found was $5.14(\mathrm{M}=5.14)$, a higher value than the mean point ( $>4)$. In conclusion, the scenario was accepted as a realist for the interviewed.

We used two filter questions to verify if, in the participants' opinion, the price of $R \$ 298,90$ could be considered a high price and the price of $\mathrm{R} \$ 89,00$ could be considered a low price for a pair of jeans: (i) "Do you considered that a pair of jeans with the price of (R\$298,90/R\$ 89,00) has:"; and (ii) "Considering jeans prices in general, the pair of jeans described above has:". A seven-point Likert scale was also used to evaluate these variables, from "1. Low price" to "7. High price".

The results indicate that for the price of $\mathrm{R} \$ 298,90$ (Scenarios 1 and 3) the mean obtained was 5.48 and for the price of $R \$ 89,00$ (Scenarios 2 and 4) the mean obtained was 2.94 ( $F=53.88$; $p=0.000$ ). Therefore, we confirmed that there was a significant difference in price level perceptions (high and low) among the participants in the different experiment scenarios. For the manipulation check of brand knowledge we ask for the answer check if the brand that him was analyzing was known or unknown. More than $99 \%$ answer correctly this question according the scenario. At the end of the experiment a debriefing was made, where was given an explanation to the participant about the pre-experiment objective and how it was made.

\subsection{Control variables}

Some variables were controlled to avoid intervening effects on the study results (Lazar et al., 2010). Therefore, five control variables were included in the analysis model, treated as covariates in the Covariance Analysis. The control variables used were: sex, age, income, product use frequency and purchase frequency (jeans). After analyzing their control effects over purchase intention, perceived value, perceived quality, perceived fairness, and symbolic value, we observed that sex, income, and use frequency did not present significant control effect over the variations of the analyzed dimensions and, therefore, they were excluded from the subsequent analyses.

However, the other two control variables presented an intervenient effect, purchase frequency presented a significant effect over purchase intention, and age presented a significant effect over the product perceived value. Later, these control variables were used in the analyses of the mentioned constructs.

\section{RESULTS ANALYSES AND DISCUSSION}

\subsection{Respondents profile}

The final sample, after the check procedures and removal of missing cases, summed up 152 participants (respondents) or valid cases, previously eliminating seven cases. The sample is characterized by sex, age, gross monthly income (individual), product use frequency and purchase frequency.

In relation to sex, $54 \%$ of the participants are male, $80 \%$ are under 30 years old, their average monthly income is between $R \$ 2.000,00$ and $R \$ 4.000,00$, they use blue jeans frequently (almost daily) and buy this product on a regular basis, that is, more than $70 \%$ of them buy the product at least each 90 days and pay, on average, $R \$ 150,00$ each pair of jeans. 
From the presented research hypotheses, the four pre-experimental scenarios were analyzed. For the hypotheses test, we used the Analysis of Variance (ANOVA) with Tukey post-hoc test and Covariance Analysis (ANCOVA), from the GLM (General Linear Model) (Hair Jr. et al., 2010).

It is worth noting that the ANCOVA was used to monitor the control variables effects. Eta partial square was used to verify the effect dimension of the independent variable over the dependent variable (Kirk, 1996). Besides, in order to test the moderation and mediation direct and indirect effects among variables, Linear Regression Analysis was applied, using bootstrapping and procedures suggested by Preacher and Hayes (2004), Zhao et al. (2010) and Hayes (2015).

\subsection{Brand and price versus perceived quality}

From the analysis of the different means, we observed that brand and price manipulation presented a significant effect over perceived quality $\left(F(1,97)=6.41 ; p<0.000 ; \eta^{2} p=0.115\right)$ such results reveal that consumers perceive quality differently for brand knowledge. Also the eta partial square of $11.5 \%$ of perceived quality variation is attributed to the influence of the independent variable brand knowledge and price level. Verifying the main effects of the model for brand knowledge $\left(F(2,74)=15,97 ; p<0,000 ; \eta^{2} p=0.096\right)$ and price level $\left(F(0,64)=1,60 ; p=0,208 ; \eta^{2} p=0,01\right)$ we observed that the perceived quality had the different score for knowledge brand than for the price level.

Figure $1 \mathrm{~A}$ shows the mean results of the four scenarios for perceived quality. As observed, high price level for known brands is perceived as of greater quality than known brands with low price levels (HP_KB=4.68 vs. LP_KB=4.15; $p=0.303$ ). However, this is not a significant difference, not supporting $\mathrm{H} 1 \mathrm{a}$. The same way $\mathrm{H} 1 \mathrm{~b}$ was not supported, once no significant difference was identified among price levels for unknown brand (HP_UB=3.53 vs. LP_UB=3.61; $p=0.994)$. Both price levels proposed for known and unknown brands did not interfere with the quality perception among these groups.

On the other hand, perceived quality for known brands is significantly higher than for unknown brands ( $K B=4,43$ vs $U B=3,57, p<0.05$ ). This happens for both price levels, high and low, for the studied product (jeans), supporting H1c. Such empirical evidence denotes brand image importance as a strong quality indicator. Therefore, for this pre-experiment, brand interfered more than the price on the respondents' quality perception. We confirmed that a brand has a significant role on a product's quality perception, and it can transmit greater value than an unknown brand for customers (Dodds \& Monroe, 1985; De Toni \& Mazzon, 2014) and that the brand needs to reinforce the perceived quality as a main element of differentiation (Gouvêa et al., 2018).

\subsection{Brand and price versus perceived fairness}

Fairness perception is an important indicator to be measured because it has a significant impact on purchase intention and brand image (Campbell, 2007; De Toni \& Mazzon, 2014). In the same direction, the pre-experiment identified that brand and price manipulation presented a significant effect over perceived fairness $\left(F(2,10)=18.99 ; p<0.000 ; \eta^{2} p=0.278\right)$ such results reveal that consumers perceive fairness differently for brand knowledge and price level. The eta partial square shows that $27.85 \%$ of perceived fairness variation is attributed to the independent variables brand knowledge and price level. As a result, the variables price and brand over perceived fairness have a good explanation power. Verifying the main effects of the model for brand knowledge $(F(2,37)=9,80$; $\left.p=0,002 ; \eta^{2} p=0.062\right)$ and price level $\left(F(2,99)=49,04 ; p=0,000 ; \eta^{2} p=0.249\right)$ we observed that the perceived farness both score for knowledge brand and price level present significant difference.

Figure $1 B$ shows perceived fairness means result from the four scenarios under study. Initially, low price levels are perceived as fairer for both known and unknown brands (HP_KB= 3.87 vs LP_KB= 
5.16, $p=0.000 ; H_{-} \_$UB $=2.99$ vs LP_UB= 4.70, $p=0.000$ ). In this case we can observe that in similar perception between brands known and also between unknown brands, the fairness perception is significantly higher for low price levels than for high price levels, this supporting the H2a. According to Xia et al. (2004), fairness perception happens when the price is compared to a reference standard, or the behavioral norm accepted by the customer. Consequently, the results point that, for jeans, with similar brand in the case to be known or unknown low prices are considered fairer than high prices.

However, there is also the influence of brand knowledge level. $\mathrm{H} 2 \mathrm{~b}$ points out that fairness perception is significantly greater for known brands than unknown ones, for both high and low price levels. This hypothesis can be support one time that the know brand can be perceived how more fairness than unknown brands ( $K B=4,47$ vs $U B=3,90, p=0.021)$. In this way, in situations of the same high price, the customer tends to attribute as fairer the price of a known brand than an unknown one. In this case, a possible explanation for the result found is the absence of other intrinsic elements that were not presented in the pre-experiment, such as the product's finish, design, color, etc., the consumer perceived the known brand how more fairness that unknown brand.

\subsection{Brand and price versus symbolic value}

Brands are consistent in systems that customers create not just to help their lives, but also to give meaning to them. The pre-experiment results indicate that brand and price manipulation presented a significant effect over symbolic value $\left(F(2,58)=7.63 ; p<0.000 ; \eta^{2} p=0.134\right)$, such results reveal that consumers perceive symbolic value differently for brand knowledge and price level. The eta partial square of $13.4 \%$ of symbolic value variation is attributed to the influence of brand and price level independent variables.. Verifying the main effects of the model for brand knowledge $\left(F(7,65)=3,45 ; p=0,065 ; \eta^{2} p=0.023\right)$ and price level $\left(F(4,15)=13,77 ; p=0,000 ; \eta^{2} p=0.085\right)$ we observed that the symbolic value had the different score for knowledge brand than price level.

Figure $1 \mathrm{C}$ demonstrates that the scenario with high price level and known brand is perceived with greater symbolic value than the low price and known brand scenario, supporting $\mathrm{H} 3 \mathrm{a}$ (HP_KB=3.70 vs LP_KB= 2.32, $\mathrm{p}=0.000$ ). However, $\mathrm{H3b}$ was not supported, because a significant difference was not observed for unknown brands in the symbolic value perception for both price levels. $\mathrm{H} 3 \mathrm{c}$ points that known brands symbolic value is significantly higher than for unknown brands, for both high and low price levels. The results evidenced that this hypothesis can only be supported for known brands with high prices, and was not supported for known brands with low prices (HP $K B=3.70$ vs HP_UB=2.76, $p=0.029$; $L P \_K B=2.32$ vs $L P \_U B=2.38, p=0.998$ ). This points out that, these pre-experiment participants perceive greater symbolic value when the brand is known and presents a high price. The expressions "it is expensive but has its value" or "it is expensive but it is good" denote, besides fairness perception, symbolic meaning for the customer that surpasses the product or service monetary value. Therefore, high price levels related to known brands or premium brands are strongly related to the product symbolic value (De Toni \& Mazzon, 2014).

\subsection{Brand and price versus purchase intention}

In order to test the effects of price level and brand knowledge over purchase intention (H5), the manipulation of brand knowledge and price level were used as factors, purchase intention as the dependent variable and purchase frequency as the covariate. The results evidenced that brand and price manipulation presented a significant effect over purchase intention $(F(0,732)=11,74 ; p<0.000$; $\eta^{2} p=0.192$ ) Such results reveal that consumers have the purchase intention differently for brand 
knowledge and price level. Also the eta partial square shows that $19,20 \%$ of purchase intention variation is attributed to the influence of the independent variables brand knowledge and price level. Verifying the main effects of the model for brand knowledge $\left(F(1,38)=19,90 ; p>0,000 ; \eta^{2} p=0.117\right)$ and price level $\left(F(0,204)=13,77 ; p=0,000 ; \eta^{2} p=0.085\right)$ we observed that the purchase intention had the same score for knowledge brand and price level.

As shown in Figure 1D, low price scenarios show greater purchase intention when compared to low price scenarios, regardless knowing the brand or not $\left(H P \_K B=3.93\right.$ vs $L P \_K B=4.93$, $p=0.003 ; H P \_U B=3.19$ vs $L P \_U B=4.16, p=0.005$ ), supporting $H 4$. These results are similar to the ones found by Gouvêa et al. (2018) where was identified that people prefer generic brand products with the lowest price than similar ones at higher prices.

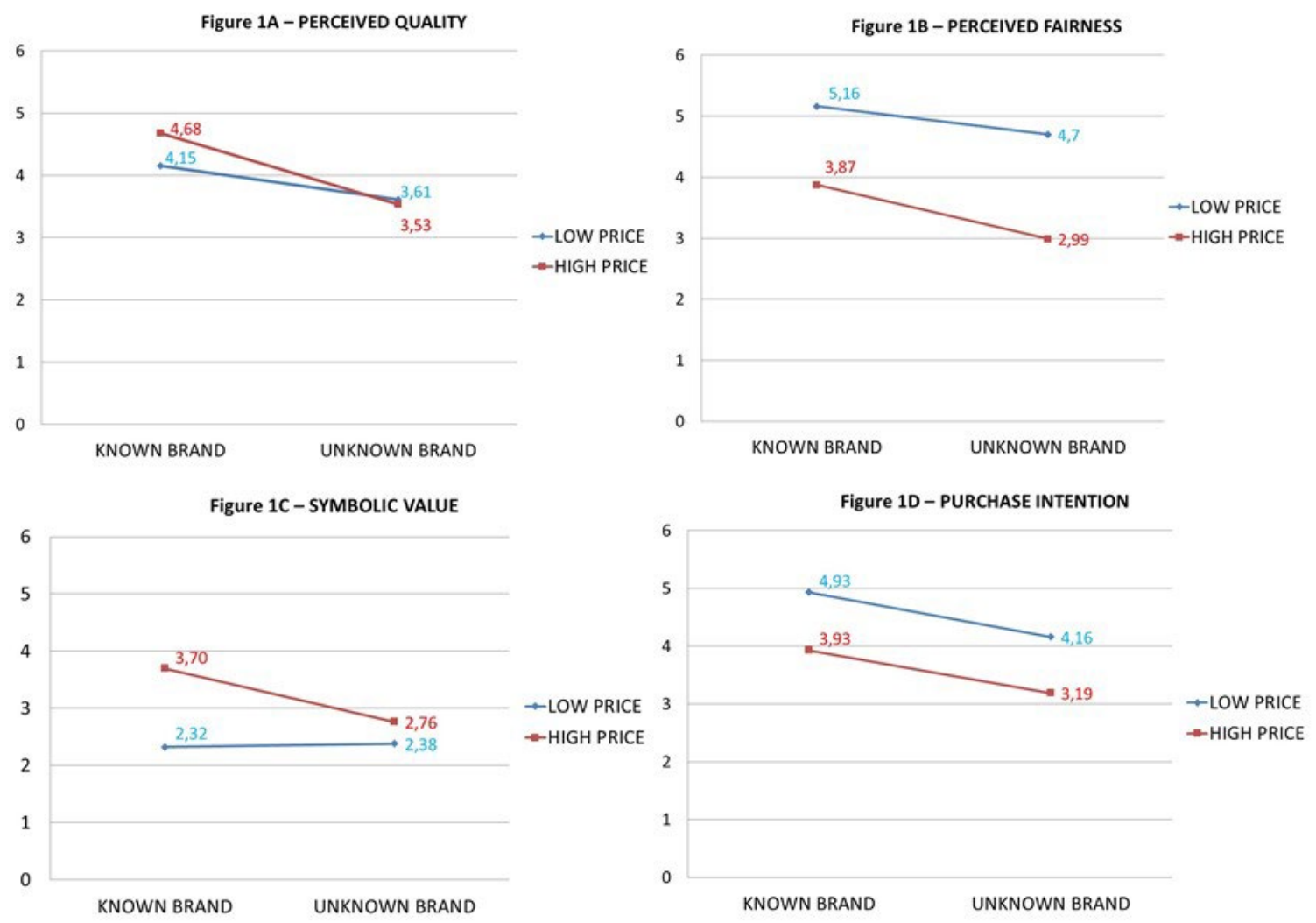

Figure 1. Scenarios Means

Source: Elaborated by the authors based on data resulting from research.

\subsection{Mediating/Moderating role of price level and brand knowledge}

Aiming to test the moderating effect of price level and brand knowledge ( $\mathrm{H} 5 \mathrm{a}$ and $\mathrm{H} 5 \mathrm{~b}$ ), we applied the procedures proposed by Hayes (2015) through The PROCESS for SPSS and plot 12 . For all results, as presented from Figures 2 and 3, we used a confidence interval of $95 \%$ calculated by means of 5.000 resamples in the bootstrapping procedure. As a result, $57 \%$ of purchase intention is explained by its moderating-mediating variables. Figure 2 shows that quality mediates the relation between symbolic value and purchase intention, although there is an indirect and significant effect from price level moderation (high and low) and brand (known and unknown) (Effect $0.39, \mathrm{Cl}=0.25$ to 0.58 ). In short, with perceived quality as the mediator, symbolic value for jeans with high price 


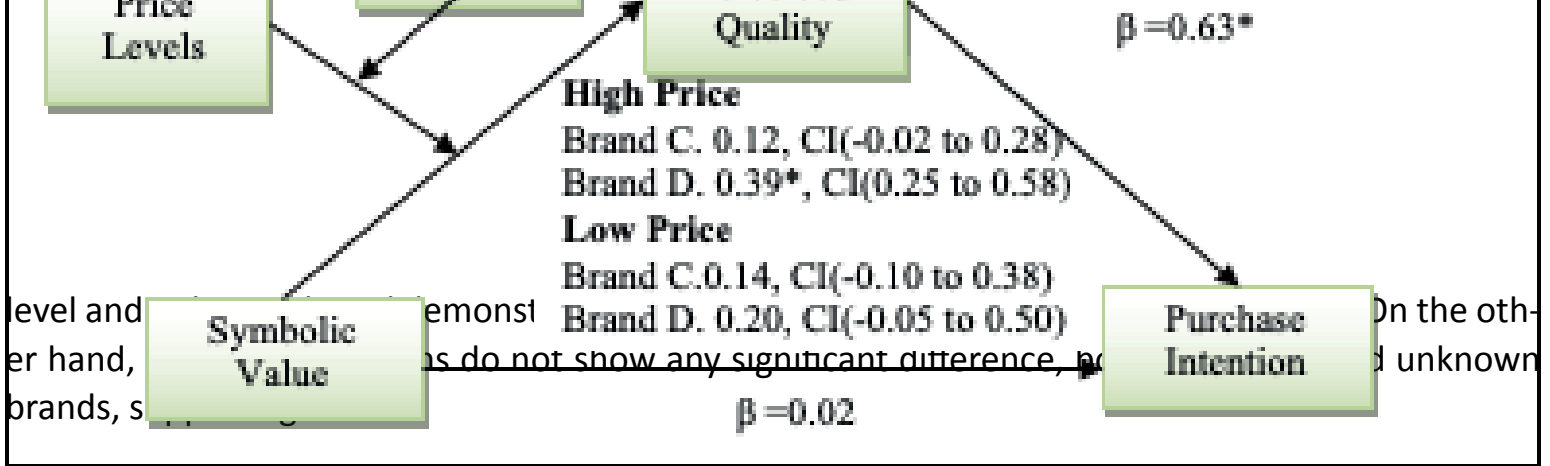

Figure 2. Price Level and Brand Knowledge Dual Moderator-Mediator and Perceived Quality Mediation

Source: Elaborated by the authors based on data resulting from research. Note: Brand C = Known Brand, Brand D = Unknown Brand; * $\mathrm{p}<0.05$.

Figure 3 illustrates that perceived fairness mediates the relation between symbolic value and purchase intention, however, there is a significant indirect effect just from price level moderation-mediation, both for known and unknown brands. Therefore, with perceived fairness as a mediator, symbolic value for jeans with high price level shows a greater indirect effect over purchase intention regardless of knowing the brand or not. Low price jeans did not present any significant difference, both for known and unknown brands. For so, H5b was partially supported.

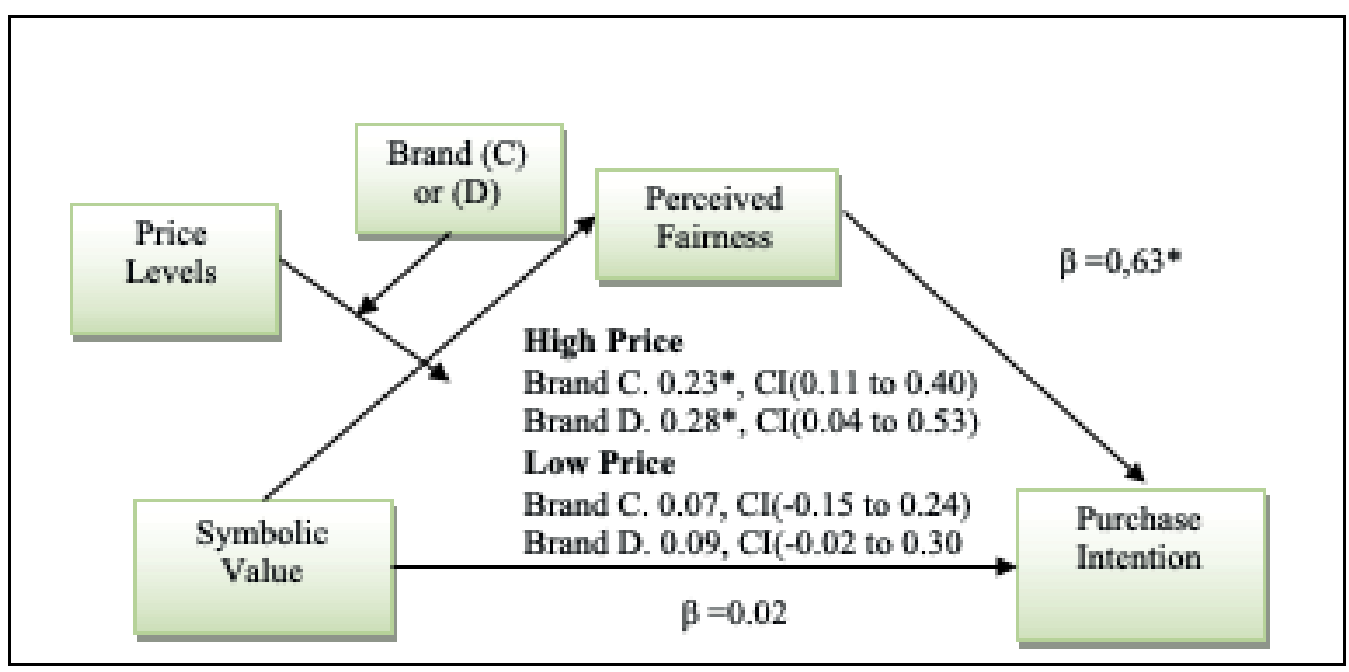

Figure 3. Price Level and Brand Knowledge Dual Moderator-Mediator and Perceived Fairness Mediation

Source: Elaborated by the authors based on data resulting from research. Note: Brand C $=$ Known Brand, Brand D = Unknown Brand; * $p<0.05$.

From the analysis of the moderating and mediating factors, we conclude that purchase decision processes are not simple and totally logical. There are a number of variables that can impact and interfere direct or indirectly over purchase intention. As for these pre-experiments, perceived value, perceived quality, and perceived fairness mediation are interfered by price level and brand knowledge level. Therefore, those are two moderating variables that need to be considered to better understand the customer purchase process. 


\section{FINAL CONSIDERATIONS}

Considering the objective of verifying price level and knowledge brand effects over perceived value, perceived quality, perceived fairness, symbolic value, and purchase intention, in an pre-experiment with jeans, we identified important research findings that help to better understand customer behavior in relation to the investigated context.

The non-confirmation of hypotheses $\mathrm{H} 1 \mathrm{a}$ and $\mathrm{H} 1 \mathrm{~b}$ refers to the perception of higher product quality for high price levels, both for known and unknown brands; and $\mathrm{H} 3 \mathrm{~b}$ refers to the perception of higher symbolic value for unknown brands at high price levels that can be associated to different factors. Himbert (2016) suggests that price is used as an external cue to assess the product quality, where higher prices lead the customer to assume that the product is of higher quality, however, this was not observed in the pre-experiment. This divergence can be associated with strange variables, or maybe price difference perception was not significant for the participant groups in the researched scenarios.

In this pre-experiment, the participants did not have access to information like, for example, brand name, country of origin, or other extrinsic cues concerning the studied objects, besides not having access to the product in physical form, in order to avoid opinion biases. However, the absence of this information may have generated in the participants, difficulties to infer about the quality of the product only from the price. For Ting (2012), the customer tends to apply this extrinsic cue in order to infer the product quality. In this way, customers can infer quality from the price when they do not have the ability or motivation to process the information related to the product or brand, or also when the search for information is difficult or there is little information available (Lowe, Lowe, \& Lynch, 2012). And this can be a possible explanation to why high price cue did not significantly impact jeans quality perception as well as the perception of greater symbolic value.

Another contribution is the identification of the constructs mediating effects. In this sense, we identified that symbolic value may not act directly over purchase intention, however, it acts indirectly, and characterizes as an important element explaining the model, presenting an adjusted $R^{2}$ of $57 \%$. The same way, the model explanation power raised when price levels (high vs low) and brand knowledge moderators were inserted. In this case, the model explanation power reached an $R^{2}$ of $68 \%$, justifying that price level and brand knowledge moderation inclusion in the model contribute to better understand how customers behave in relation to purchase intention. The results of the moderated mediation model and the interaction between both brand knowledge and price level also brought an important contribution to an understanding of how buying behavior operates in these different conditions.

We also identified that symbolic value for jeans with high price level and unknown brand demonstrate a greater indirect effect over purchase intention, mainly through perceived quality and value mediation, where low prices on jeans show no difference, both for known and unknown brands. In other words, both the price level and brand knowledge or not show that they have a different impact on the consumer's shopping journey. Considering these two elements in the configuration of marketing strategies is decisive to be more assertive in decisions.

There are many variables that impact the purchase intention. In the case of this research, we identified the moderation of the price level of a product, but other studies can be conducted, using as scenario physical or virtual stores. For example, a customer interested in buying some wine at a moderate price can look for this wine in a specialized store with high prices image, whereas, according to reference price theory, this customer will fix the reference price upwards to adjust this retailer price image as favorable.

Another situation, according to Hamilton and Urminsky (2013) studies, is that customers prefer buying the same products from the same brand with a low economic value in retailers with high price image. In this sense, customers identify in these stores greater aggregate value based 
on architecture structure, service offered and the facility symbolism. Such findings show that price levels perception is also contingent and suffers significant influence from the price image that either the brand or the commercial establishment have.

By understanding how customers integrate, relate and infer quality, fairness and symbolic aspects to products through their perceptions concerning price levels and brand knowledge levels, it is possible to supply marketing professionals with information that lead to better-informed choices about pricing policy and branding in their companies. Besides, considering that such information is important to direct communication and brand reinforcement campaigns, because understanding how price levels and brand knowledge levels impact customers' perceptions and behavior, managers can concentrate efforts in these important attributes that englobe marketing. In a practical way, the investment in brand knowledge has the power of influencing a better market positioning, increasing the companies' products purchase or repurchase intention, positively impacting revenue, market share, and profitability.

Among these research limitations, we observe that an pre-experiment can have several strange variables that interfere with the results, and we emphasize some situations that could have resulted in that. The non-confirmation of hypotheses $\mathrm{H} 1 \mathrm{a}$, for example, that the known brand present one higher perceived value than unknown brand with the similar price can be one limitation of the pre-experiment and not necessarily of the theory. The first refers to the non-identification of a specific brand. In this case, what may have happened is that the simple fact of informing that it was a known brand of jeans without giving the brand a name, perhaps did not awaken a more realistic image of the product, on the other hand, having a specific brand could create a significant bias in the study. In this sense, it would be interesting to incorporate specific and non-specific brands scenarios in future experiments and compare the results.

As a pre-experiment, this research hasn't presented a neutral scenario, for future research treatment with null active principle can be implemented. A second limitation could be the lack of stimulus to respondents by not having contact with the physical product. The lack of intrinsic elements, such as color, texture, model, etc., perhaps made it more difficult for the respondent to have a realist picture of the context. Anyway, this could also lead to higher response bias, since each customer may have different preferences concerning intrinsic elements. For this reason, future studies could consider different scenarios, with more intrinsic elements about the product and verify the effects of the analyzed constructs.

Finally, price image, that can have symbolic and utilitarian elements in its configuration, like fairness, value and quality perception and emotional elements (De Toni \& Mazzon, 2014). The same way these elements can be influenced by factors based on the retailer, such as price-related factors (price policy, mean price levels, price dispersion) and factors not related to price (store physical attributes, service level) (Hamilton \& Chernev, 2013). From this, it is possible that new experiments aggregate in their scenarios some of these elements, such as the physical environment of the commercial establishment, for example, stores with an image of a sophisticated environment versus stores with more economical environments. Thus, a scenario 2 (high price vs. low price) $\times 2$ (known brand vs. unknown brand) $\times 2$ (sophisticated environment vs. economic environment) aiming to identify these variables effects over the customer behavior, would bring an important contribution to academic and managerial contexts. This study approached some constructs that build customer perception, however, there are other constructs that also interfere customer perception and purchase intention, such as brand love (Anggraenia \& Rachmanita, 2015) and the customer experience (Lemon \& Verhoef, 2016). In this sense, future studies can incorporate these or other constructs and measure price level, brand knowledge and physical environment effects over the analyzed constructs. 


\section{REFERENCES}

Ajzen, I. (1991). The theory of planned behavior. Organizational Behavior and Human Decision Processes, 50(2), 179-21.

Anggraenia, A.; Rachmanita. (2015). Effects of brand love, personality and image on word of mouth: the case of local fashion brands among young consumers. Procedia Social and Behavioral Sciences, 211,442-447.

Barber, N.; Kuo, P.; Bishop, M.; Goodman, R. (2012). Measuring psychographics to assess purchase intention and willingness to pay. Journal of Consumer Marketing, 29(4), 280-292.

Bolton, L. E.; Warlop, L.; Alba, J. W. (2003). Consumer perceptions of price (un)fairness. Journal of Consumer Research, 29(4), 474-491.

Campbell, M. C. (2007). Says who?! How the source of price information and affect influence perceived price (un)fairness. Journal of Marketing Research, 44(2), 261-271.

Chang, T. Z.; Wildt, A. R. (1994). Price, product information, and purchase intention: an empirical study. Journal of the Academy of Marketing Science, 22(1), 16-27.

Chung, H.; Lee, E. (2017). Store brand quality and retailer's product line design. Journal of Retailing, 93(4), 527-540.

De Toni, D.; Mazzon, J. A. (2014). Teste de um modelo teórico sobre o valor percebido do preço de um produto. Revista de Administração (São Paulo), 49(3), 549-565.

De Toni, D.; Mazzon, J. A.; Milan, G. S. (2015). A multidimensionalidade da imagem de preço de produto: um estudo com a imagem de preço de vestuário. Revista de Administração da Mackenzie, São Paulo, 16(4), 168-201.

Diallo, M. F.; Coutelle-Brillet, P.; Riviére, A.; Zielke, S. (2015) How do price perceptions of different brand types affect shopping value and store loyalty? Psychology \& Marketing, 32(12), 1133-1147.

Dichter, E. (1985). What's in an image. Journal of Consumer Marketing, 2(1), 75-81.

Diller, He. (2008). Price fairness. Journal of Product \& Brand Management, 17(5), 353-355.

Dobni, D.; Zinkhan, G. M. (1990). In search of grand image: a foundation analysis. Advancesin Consumer Research, 17(1), 110-119.

Dodds, W. B.; Monroe, K. B. (1985). The effect of brand and price information on subjective product evaluations. Advances in Consumer Research, 12, 85-90.

Dodds, W.; Monroe, K.; Grewal, D. (1991). Effects of price, brand, and store information on buyers' product evaluations'. Journal of Marketing Research, 28, 307-319.

Goldsmith, R. E.; Flynn,L. R.; Kim, D. (2010). Status consumption and price sensitivity. Journal of Marketing Theory and Practice, 18(4), 323-338.

Graciola, A. P.; De Toni, D.; De Lima, V. Z.; Milan, G. S. (2018). Does price sensitivity and price level influence store price image and repurchase intention in retail markets? Journal of Retailing 
and Consumer Services, 44, 201-2013.

Ha-Brookshire, J. E. (2012). Country of parts, country of manufacturing, and country of origin: Consumer purchase preferences and the impact of perceived prices. Clothing and Textile Research Journal, 30(1), 19-34.

Hair Jr. J. F.; Black, W. C.; Babin, B. J.; Anderson, R. E. (2010). Multivariate data analysis. $7^{\text {th }}$ edition. New York: Prentice Hall.

Hamilton, R.; Urminsky, O. (2013). Inference not reference: the price image heuristic as an alternative to reference price theories. Emory University.

Hamilton, R; Chernev, A. (2013). Low prices are just the beginning: price image in retail management. Journal of Marketing, v. 77, n. 6, p.1-20, nov.

Hansen, J. E. (2005). A slippery slope: how much global warming constitutes "dangerous anthropogenic interference"? An editorial essay. Climatic Change, 68(3), 269-279.

Hayes, A. F. (2015). An index and test of linear moderated mediation. Multivariate Behavioral Research, 50(1), 1-22.

Himbert, L. (2016). Unit pricing: empirical investigations of its influences at the product and retailer levels. 2016. Dissertation Technische Universität Kaiserslautern.

Kardes, Frank R. (2002). Consumer behavior and managerial decision making. Saddle River: Prentice Hall.

Keller, K. L. (1993). Conceptualizing, measuring, and managing customer-based brand equity. Journal of Marketing, 57, 1-22, 1993.

Keppel, G. (1991). Design and analysis: a researcher's handbook. Upper Saddle River: Prentice Hall.

Kinnear, T. C.; Taylor, J. R. (1996). Marketing research: an applied approach. $5^{\text {th }}$ edition. New York: McGraw-Hill.

Kirk, R. (1996). Practical significance: a concept whose time has come. Educational and Psychological Measurement, 56, 746-759.

Kukar-Kinney, M.; Xia, L.; Monroe, K.B. (2007). Consumers' perceptions of the fairness of price matching refund policies. Journal of Retailing, 83(3), 325-337.

Kukar-Kinney, M.; Ridgway, N. M.; Monroe, K. B. (2012). The role of price in the behavior and purchase decisions of compulsive buyers. Journal of Retailing, 88(1), 63-71.

Lazar, J.; Feng, J. H.; Hochheiser, H. (2010). Research methods in human-computer interaction. London: Wiley, 2010.

Lehmann, D. R.; Gupta, S.; Steckel, J. H. (1998). Marketing research. Reading: Addison Wesley.

Lemon, K., N.; Verhoe, P. C. (2016). Understanding customer experience throughout the customer journey. Journal of Marketing, 80(6), 69-96.

Levy, S. J. (1981). Interpreting consumer mythology: a structural approach to consumer behavior. Journal of Marketing, 45(3), 49-61. 
Lichtenstein, D.; Ridgway, N.; Netemeyer, R. (1993). Price perception and consumer shopping behavior: field study. Journal of Marketing Research, 30(2), 234-245.

Lowe, B.; Lowe, J.; Lynch, D. (2012). Behavioral aspects of pricing, in innovations in pricing: contemporary theories and practice. In: Hinterhuber, A.; Liozu, S. (Eds.). Innovation in Pricing: contemporary theories and best practices. New York: Routledge.

Malhotra, N. K.; Birks, D.; Wills, P. (2012). Marketing research: applied approach. $4^{\text {th }}$ edition. New York: Pearson.

Monroe, K. B.; Krishnan, R. (1985). The effect of price on subjective product evaluations. In: Jacoby, J.; Olson, J. (Eds.) Perceived quality. Lexington: Lexisgton Books, 209-232.

Newman, C. L.; Turri, A. M.; Howlett, E.; Stakes, A. (2014). Twenty years of country-of origin food labeling research: a review of the literature and implications for food marketing systems. Journal of Micromarketing, 1, 1-15.

Nisbett, R. E.; Ross, L. (1980). Human inference: strategies and shortcomings of social judgment. Englewood Cliffs, NJ: Prentice-Hall.

O'Cass, A.; Frost, H. (2002). Status brands: examining the effects of non-product-related brand associations on status and conspicuous consumption. Journal of Product and Brand Management, 11(2), 67-88.

O'Neill, R; Lambert, D. (2001). The emotional side of price. Psychology \& Marketing, 18(3), 217-237.

Olaru, D.; Purchase, S.; Peterson, N. (2008). From customer value to repurchase intentions and recommendations. Journal of Business \& Industrial Marketing, 23(8), 554-565.

Park, B.; Jaworski, B. J.; Macinnis, D. J. (1986). Strategic brand concept-image measurement. Journal of Marketing, 50(4), 135-145.

Peter, J. Paul; Olson, Jerry C. (2010). Consumer behavior \& marketing strategy. $9^{\text {th }}$ edition. New York: McGraw-Hill Irwin.

Peterson, R. (2001). On the use of college students in social science and research: insights from a second-order meta-analysis. Journal of Consumer Research, 28(3), 450-461.

Preacher, K. J.; Hayes, A. F. (2004) SPSS and SAS procedures for estimating indirect effects in simple mediation models. Behavior Research Methods, Instruments, \& Computers, 36(4), 717-731.

Ramayah, T.; Lee, J. W. C.; Mohamad, O. (2010). Green product purchase intention: some insights from a developing country. Resources, Conservation and Recycling, 54(12), 1419-1427.

Scitovsky, T. (1945). Some consequences of the habit of judging quality price. Review of Economics Studies, 12, 100-105.

Shapiro, B. P. (1973). Price reliance: existence and sources. Journal of Marketing Research, 10(3), 286-294.

Sheau-Fen, Y.; Sun-Way, L.; Yu-Ghee, W. (2012). Store brand proneness: effects of perceived risks, quality and familiarity. Australian Marketing Journal, 20, 48-58. 
Stern, B.; Zinkhan, G. M.; Jaju, A. (2001). Marketing images: construct definition, measurement issue, and theory development. Marketing Theory, 1(2), 201-224.

Sweeney, J. C.; Soutar, G. N.; Johnson, L. W. (1999). The role of perceived risk in the quality-value relationship: a study in a retail environment. Journal of Retailing, 75(1), 77-105.

Teas, R. K.; Agarwal, S. (2000). The effects of extrinsic cues on consumers' perceptions of quality, sacrifice, and value. Journal of the Academy of Marketing Science, 28(4), 278-290.

Ting, S.C. (2012). How need for cognition moderates the influence of country of origin and price on consumer perception of quality. Social Behavior and Personality, 40(4), 529-544.

Vigneron, F.; Johnson, L. W. (1999). A review and a conceptual framework of prestigeseeking behavior. Academy of Marketing Science Review, 1, 1-15.

Völckner, F.; Hofmann, J. (2007). The price-perceived quality relationship: a meta-analytic review and assessment of its determinants. Marketing Letters, 18(3), 181-196.

Xia, L.; Monroe, K. B.; Cox, J. L. (2004). The price in unfair! A conceptual framework of price fairness perceptions. Journal of Marketing, 68, 1-15.

Wilson, T. D., Aronson, E., Carlsmith, K. (2010). The art of laboratory experimentation. In: Fiske, S. T.; Gilbert, D. T.; Lindzey, G. L. (Eds.). Handbook of social psychology. Hoboken: Wiley, 51-58.

Yeung, C. W. M.; Soman, D. (2007). The duration heuristic. Journal of Consumer Research, 34, 315-326.

Yuan, Hong; Han, Song. (2011). The effects of consumers' price expectations on sellers' dynamic pricing strategies. Journal of Marketing Research, 48(1), 48-61.

Zeithaml, V. A. (1988). Consumer perceptions of price, quality, and value: a means end model and synthesis of evidence. Journal of Marketing, 52, 2-22.

Zhao, X.; Lynch, G. J.; Chen, Q. (2010). Reconsidering Baron and Kenny: myths and truths about mediation analysis. Journal of Consumer Research, 37(2), 197-206.

Zielke, S. (2006). Measurement of retailers' price images with a multiple item scale. Int. Rev. of Retail. Distribution and Consumer Research, 16, 297-316.

Zielke, S. (2010). How price image dimensions influence shopping intentions for different store formats. European Journal of Marketing, 44, 748-770.

Zielke, S. (2011). Integrating emotions in the analysis of retail price images. Psychology \& Marketing, 28, 330-359.

Aaker, D.A. (1991). Managing Brand Equity: Capitalizing on the Value of a Brand Name. The Free Press, New York.

Anselmsson, J., Bondesson, N.V. and Johansson, U. (2014). Brand Image and Customers Willingness to Pay a Price Premium for Food Brands. Journal of Product \& Brand Management, 23 (2), 90-102.

De Toni, D., Bacichetto, V.D., Milan, G.S., \& Larentis, F. (2014). A Relação entre Conhecimento da Marca e Nível de Preço na Intenção de Compra: Um Experimento com Perfumes de Luxo. Revista Brasileira de Marketing - ReMark, 13 (3), 108-124. 
Gouvêa, M., Castro, L., \& Vicente, N. (2018). The brand types influence on the choice and pricing of a T-shirt. Revista de Administração da UFSM, 11 (3), 595-614.

KAPFERER, J. N. (2004). Marcas à prova de prática: aprendendo com os erros. 2. ed. Porto Alegre: Bookman.

Koschate-Fischer, N. and Wüllner, K. (2017). New developments in behavioral pricing research. J Bus Econ, 87, 809-875.

Lombart, C., Louis, D., and Labbé-Pinlon, B. (2016). Price image consequences. Journal of Retailing and Consumer Services, 28 (1), 107-116.

Pizzinatto, N., Cunha, C., Sarquis, A., Pizzinatto, A., \& Lopes, E. (2020). Determinant attributes valued by Brazilian retail construction materials consumers. Revista de Administração da UFSM, 13 (3), 501-516.

Zielke, S. (2014). Shopping in Discount Stores: The Role of Price-related Attributions, Emotions and Value Perception. Journal of Retailing and Consumer Services, 21 (3), 327-338.

\section{AUTHORS}

\section{Deonir De Toni}

Universidade de Caxias do Sul (UCS), Caxias do Sul/RS - Brazil.

Professor and researcher at University of Caxias do Sul (UCS). Associate Professor of Business Administration from University of São Paulo (USP), Doctor of Administration from University Federal do Rio Grande do Sul (UFRGS)

E-mail: dtoni2@ucs.br

ORCID: https://orcid.org/0000-0001-9637-8099

\section{Andressa Tormen}

Universidade de Caxias do Sul (UCS), Caxias do Sul/RS - Brazil.

Graduate Program in Administration in the University of Caxias do Sul (UCS).

Marster of Business Administration from University of Caxias do Sul (UCS)

E-mail: andressatormen@gmail.com

ORCID: https://orcid.org/0000-0002-3899-8764

\section{Gabriel Sperandio Milan}

Universidade do Vale do Rio dos Sinos (Unisinos), São Leopoldo, Rio Grande do Sul, Brazil.

Professor and researcher at University of Vale do Rio dos Sinos (Unisinos). PhD in Production Engineering focusing Quality Systems from the Federal University of Rio Grande do Sul (UFRGS).

E-mail: gsmilan@unisinos.br

ORCID: https://orcid.org/0000-0003-3480-2653

\section{Luciene Eberle}

Universidade do Vale do Rio dos Sinos (Unisinos), São Leopoldo, Rio Grande do Sul, Brazil.

Professor and researcher at PPGA - Postgraduate Program in Administration (Master's Courses in Administration) at UCS in the period 2002-2021. Post-doctoral student in the Production and Systems Engineering Program at the University of Vale do Rio dos Sinos - UNISINOS. PhD in Business Administration from Associação Ampla PUCRS - Pontifical Catholic University of Rio Grande do Sul and UCS - University of Caxias do Sul. Master in Administration from UCS. E-mail: leberle@edu.unisinos.br

ORCID: 0000-0002-0282-5626 


\section{Fernanda Lazzari}

Universidade de Caxias do Sul (UCS), Caxias do Sul, Rio Grande do Sul, Brazil.

Professor and researcher at University of Caxias do Sul (UCS), Caxias do Sul/RS -Brazil. Doctor of Administration from University Federal do Rio Grande do Sul (UFRGS)

E-mail: flazzar3@ucs.br

ORCID: https://orcid.org/0000-0002-6480-0547

\section{Ana Paula Graciola}

Universidade do Vale do Rio dos Sinos (Unisinos), São Leopoldo, Rio Grande do Sul, Brazil.

Doctor and Master's degree in Business Management by the University of Caxias do Sul. Researcher at Unisinos University as Postdoctoral.

E-mail: anagraciola@gmail.com

ORCID: orcid.org/0000-0002-1389-5072

\section{Contribution of authors}

\begin{tabular}{|c|c|c|c|c|c|c|}
\hline Contribution & [Author 1] & [Author 2] & [Author 3] & [Author 4] & [Author 5] & [Author 6] \\
\hline $\begin{array}{l}\text { 1. Definition of research } \\
\text { problem }\end{array}$ & $\sqrt{ }$ & $\sqrt{ }$ & $\sqrt{ }$ & & & \\
\hline $\begin{array}{l}\text { 2. Development of hypoth- } \\
\text { eses or research questions } \\
\text { (empirical studies) }\end{array}$ & $\sqrt{ }$ & & $\sqrt{ }$ & & & \\
\hline $\begin{array}{l}\text { 3. Development of theoreti- } \\
\text { cal propositions } \\
\text { (theoretical work) }\end{array}$ & $\sqrt{ }$ & V & $\sqrt{ }$ & & & \\
\hline $\begin{array}{l}\text { 4. Theoretical foundation / } \\
\text { Literature review }\end{array}$ & $\sqrt{ }$ & $\sqrt{ }$ & $\sqrt{ }$ & & & \\
\hline $\begin{array}{l}\text { 5. Definition of methodologi- } \\
\text { cal procedures }\end{array}$ & $\sqrt{ }$ & & & $\sqrt{ }$ & $\sqrt{ }$ & $\sqrt{ }$ \\
\hline 6. Data collection & & $\sqrt{ }$ & & & & $\sqrt{ }$ \\
\hline 7. Statistical analysis & $\sqrt{ }$ & & & $\sqrt{ }$ & & $\sqrt{ }$ \\
\hline $\begin{array}{l}\text { 8. Analysis and interpretation } \\
\text { of data }\end{array}$ & $\sqrt{ }$ & & & $\sqrt{ }$ & & $\sqrt{ }$ \\
\hline $\begin{array}{l}\text { 9. Critical revision of the } \\
\text { manuscript }\end{array}$ & & & & & $\sqrt{ }$ & \\
\hline 10. Manuscript writing & $\sqrt{ }$ & $\sqrt{ }$ & & & $\sqrt{ }$ & \\
\hline $\begin{array}{l}\text { 11. Other (adjustment of pa- } \\
\text { per from the reviewers) }\end{array}$ & $\sqrt{ }$ & & $\sqrt{ }$ & & $\sqrt{ }$ & \\
\hline
\end{tabular}

\section{Conflict of Interest}

The authors have stated that there is no conflict of interest.

\section{Copyrights}

ReA/UFSM owns the copyright to this content.

Plagiarism Check

The ReA/UFSM maintains the practice of submitting all documents approved for publication to the plagiarism check, using specific tools, e.g.: CopySpider. 
Rev. AdM. UFSM, SANTA MARIA, V. 14, N. 3, JUL.-SEP., P. 632-654, 2021 - 654 - 